\title{
Debt Rule Federalism: The Case of Germany
}

\author{
by Sarah Ciaglia* ${ }^{*}$ and Friedrich Heinemann
}

In 2009, Germany introduced a new debt rule in its federal constitution (Grundgesetz). The so-called "debt brake" prescribes a balanced budget for both the federal level and the states. However, the states have leeway regarding transposition and specification of the national requirements into their own state constitutions and budgetary laws. This analysis presents a comprehensive comparison of the 16 state provisions. We develop an indicator which quantifies the stringency of these rules. Two key results emerge: First, despite the common constitutional rule at the federal level, the analysis reveals a considerable heterogeneity across German states. Second, several highly indebted states miss the chance to make their fiscal regime more credible. This finding corresponds to disincentives within the German federation. Due to bailout-guarantees enshrined in German federalism, German states do not have incentives to impress bond markets through particularly strict budgetary rules.

Deutschland schrieb 2009 eine neue Schuldenregel im Grundgesetz fest. Diese sogenannte „Schuldenbremse“ sieht sowohl für den Bund als auch die Länder ein ausgeglichenes Budget vor. Die Bundesländer verfügen in der Umsetzung und Konkretisierung der nationalen Vorgaben in Landesverfassungen und Gesetze allerdings über einigen Spielraum. Die nachfolgende Analyse beinhaltet einen umfassenden Vergleich der 16 Landesregelungen. Wir entwickeln dazu einen Indikator, der die Strenge der Länderregeln abbildet und zwei zentrale Ergebnisse erbringt: Zum einen findet sich trotz der einheitlichen Bundesregel eine beträchtliche Heterogenität zwischen den deutschen Bundesländern; zum zweiten lassen einige der hoch verschuldeten Staaten die Chance, ihr Fiskalregime glaubwürdiger zu machen, ungenutzt. Dieses Ergebnis korrespondiert mit Fehlanreizen im Rahmen des deutschen Föderalismus. Aufgrund der gegebenen Beistandsgarantien verfügen die deutschen Bundesländer über keine Anreize, die Anleihemärkte durch besonders strenge Budgetregeln zu beeindrucken.

\section{Introduction}

Federal structures provide the potential that sub-national jurisdictions follow individual policies which, compared to a unitary government, can better be tailored according to heterogeneous voter preferences. This chance, however, may

* The views expressed in this paper are those of the author and do not necessarily represent those of the Federal Ministry of Finance. 
imply a risk when it comes to the need of credible and consistent country-wide constitutional rules. If a country tries to enhance its fiscal credibility through new budgetary rules, a transposition leeway of sub-national jurisdictions could weaken these rules' effectiveness and credibility. This risk can be assumed to be particularly present in countries with a high degree of constitutional autonomy of sub-national jurisdictions. The problem has been present in Europe since the establishment of the Euro and the Stability and Growth Pact. Rules which were designed to commit EU member countries suffered from a deficient transposition in the federal context of member countries. In the current European debt crisis, governments are struggling to strengthen or regain market confidence through more credible fiscal rules, such as agreed upon in the Fiscal Compact. But, here again, federal structures may complicate the establishment of consistent and credible fiscal institutions.

Germany is a federal country for which these considerations are relevant, too, thus posing a promising case. In 2009, the country introduced a new debt brake which aims at constraining the build-up of new public debt at both the federal and the state level. While the new rule is enshrined in the federal constitution, the 16 states have leeway on how to mirror these national rules in their state constitutions and budgetary state laws. Although the debt brake of the Grundgesetz is immediately binding for the states as well, the individual state transposition could create quite a diverse set of effective fiscal rules across states. ${ }^{1}$ Hence, a similar problem in the context of federal states exists as it is given with the national transposition leeway of the Fiscal Compact in the EU.

It is the objective of this contribution to shed light on this issue and to ask to which extent German states' debt rules differ. Germany is without doubt a particularly interesting and important example of debt rule federalism since the debt brake has had a strong impact on the design of the rules agreed upon in the Fiscal Compact. In our analysis we go beyond a mere qualitative description of institutional differences and develop a quantitative indicator which expresses the strictness of the rules. The indicator's construction follows approaches developed in the current literature to compare fiscal rules across countries (see section 4 below).

1 This has also been the case before the 2009 constitutional reform. However, the old constraint (according to which the deficit was not allowed to exceed the level of public investment) suffered from a generous escape clause related to the existence of a macroeconomic disequilibrium. Thus, the national rule was inherently non-binding with the consequence that different state transposition was of less relevance (see section 2). 
Our results point towards a considerable heterogeneity of budgetary rules across German states in spite of the existence of the overall federal constitutional rule. For example, states differ with respect to the legal basis of their debt rules, the rule's precision, the chosen flexibility provisions and its comprehensiveness. Furthermore, only in the poorest states the rules' credibility gains from effective sanction provisions as these states risk the cut-off from transfers if they do not adhere to the rules. This partially explains that, according to our indicator, the strongest rules are currently to be found in financially weak states (SaxonyAnhalt, Schleswig-Holstein, and Saarland). However, this advantage will expire in the year 2020 when the financial consolidation support ends. A possible reason for the lack of ambition in some states would point at specific disincentives of German federalism: Due to bailout-guarantees states do not have incentives to impress bond markets through particularly strict budgetary rules.

\section{The German Debt Brake}

In 2009, Bundestag and Bundesrat decided to implement a stricter budget rule in the federal constitution. It includes constraints on the level of the structural deficit for both the federal government (deficit must not exceed $0.35 \%$ of the GDP, binding from 2016 onwards) and the states (deficit must be zero or in surplus from 2020 onwards, art. 143d [1] GG). Since the rule prohibits, in principle, new net borrowing, it is called "debt brake". The rule has been further specified by the implementation of the Fiscal Compact ( $H G r G \$ 51$ [2]) which came into force in 2013. The Fiscal Compact prescribes a $0.5 \%$ structural deficit limit for all government entities together (federal level, states, municipalities and social security insurances). However, the exact breakdown of the limit across government entities is not specified yet, thus giving room to the "Stability Council" (Stabilitätsrat) to coordinate the distribution.

This "Stability Council" monitors compliance with the budget rules and with the regulations according to the Consolidation Assistance Act (Konsolidierungshilfengesetz, KonsHilfG, based on art. 109a GG). The Council comprises the finance ministers of each state, the federal ministers of finance and of economic affairs. Every state and the federal government have one vote each; the federal level ministers share one vote. However, the federal government disposes of a veto: Decisions require a two-thirds majority of the states and the vote of the federal government. Decisions concern the definition of common measures and benchmarks, or the official identification of a rule violation by a member. In the latter case, the Council member representing the violator - a state or the federal 
government - has no voting right. In case of an identified violation, the Council sets up a stability programme together with the respective government and monitors its enforcement.

However, the Stability Council does not dispose of means to sanction misbehaviour, only for those states that receive temporary financial support. These states are considered not to be able to achieve a balanced budget in 2020 on their own; these are: Berlin, Bremen, Saarland, Saxony-Anhalt and Schleswig-Holstein (art. $143 \mathrm{~d}$ [2] GG). In return for the financial support, the states agreed to reduce their structural deficit ${ }^{2}$ along yearly decreasing limits ( $\$ 2$ [1] KonsHilfG). If a state does not comply with these limits, financial support is cut off ( $§ 1$ [3] sentence 3 KonsHilfG). The federal government and all states - including those receiving financial support - pay half of the total yearly amount of $800 \mathrm{~m}$ Euro (art. 143d [3] $G G)$.

The German debt brake has been discussed controversially among scholars of economics and law. On the one hand, the rule is regarded as a step forward: compared to its predecessor the new rule is considered to be "balanced and effective". ${ }^{3}$ Up to the 2009 reform, the German constitution prescribed a "golden rule" with net borrowing limited to the level of gross public investment. ${ }^{4}$ Its effectiveness was massively impaired by the existence of a very general escape clause: declaring a 'macroeconomic disequilibrium' was sufficient to legitimate a violation of the general principle. As any significant level of unemployment, trade balance, inflation or poor growth was sufficient for such an assessment, the old rule has not been an effective constraint. Between 1991 and 2005, the federal level missed the golden rule in seven and the states in 68 cases. ${ }^{5}$ Given this reference point, the new debt brake is clearly more precise with respect to the deficit ceiling (i.a. no need to define the term "investment"), the exception clauses and its surveillance.

2 The calculation of the structural deficit is defined in the Consolidation Assistance Act (\$ 2 [1] KonsHilfG) and the respective Administrative Agreements (Verwaltungsvereinbarung [VV] KonsHilfG). Each federal state agrees to an individual administrative agreement with the federal ministry of finance $(V V$ KonsHilfG). These agreements define in detail the calculation of the structural deficit, the process of support and possible sanctions following non-compliance.

3 Feld, L.: Sinnhaftigkeit und Effektivität der deutschen Schuldenbremse, in: Perspektiven der Wirtschaftspolitik, 11/3 (2010), 226-245, here 241.

4 Some state budget rules still mirror this "golden rule". In this context, the Budgetary Principles Act (Haushaltsgrundsätzegesetz, HGrG) determines the term "investments" (HGrG art. 20 [3] 2 sentence 2) and is still important for many budget rules in the states and for the federal government until 2015, too. The term "investment" is notoriously imprecise and has been interpreted extensively.

5 Feld, L, op.cit., 232. 
Despite of the progress made, as compared to the pre-2009 situation, the new rule is far from a perfect solution. ${ }^{6}$ A shortcoming which is also admitted by principle defendants of the new rule is the missing availability of effective sanctions. Any significant reform would have required increasing tax autonomy of German states which could safeguard the ability to pay fines. As an increase in revenue autonomy was not acceptable for numerous states, this precluded the establishment of effective fiscal sanctions (beyond the implicit sanctioning of the consolidation assistance as mentioned). Apart from that, the Stability Council's composition does not guarantee a neutral and unbiased analysis since neutral representatives with voting rights (e.g. from the German Bundesbank) are missing. Furthermore, the ceilings for the budgeted deficits only refer to the central level and the state level and do not take account of deficits of the social security systems or the municipal level. Payments to both are part of the state budgets, but independent borrowing by them is not. This offers leeway for "fiscal cosmetics". Whereas the long transitory period between 2009 and 2020 serves as a legitimate strategy of a lagged reform implementation which is to overcome political-economic resistance, problems of time inconsistency could arise as a consequence of the long transitory phase, too. ${ }^{7}$ The resistance against the new constraints is likely to grow until the brake enters into force.

Already these shortcomings indicate that the new debt brake is not perfect so that states could, in principle, embark on a more stringent rule for their own budgetary constitution. Although the rules and procedures of the federal constitution bind the actors, there is scope for deciding on several details of implementation:

- Method of structural adjustment: The constitution states that the annual public budget of the states must be balanced without new borrowing "in principle" (art. 109 [3] sentence 1 and $5 G G$ ). The target is understood to refer to the accounting balance (Finanzierungssaldo). ${ }^{8}$ To implement this strict rule the constitution allows the states to define provisions to adjust the budgetary balance for business cycle developments in a "symmetric" way (art. 109 [3] sentence $2 G G$ ). In an economic downturn, the state is allowed to borrow but must repay the extra debt in an economic upswing. The fed-

6 Ibid.; Sturm, R.: Verfassungsrechtliche Schuldenbremsen im Föderalismus, in: Zeitschrift für Parlamentsfragen, 3 (2011), 648-662.

7 Heinemann, F.: Eine Gabe an St. Nimmerlein? Zur zeitlichen Dimension der Schuldenbremse, in: Perspektiven der Wirtschaftspolitik, 11/3 (2010), 246-259.

8 Deutsche Bundesbank: Monatsbericht Oktober 2011, 15-40, here 16; Thye, M.: Die neue „Schuldenbremse" im Grundgesetz, Halle, 2010, 25f. According to the $H G r G$ the accounting balance considers all incomes and expenditures (including interest rate payments) except for those related to credit market borrowing, reserves, cash surpluses or deficits and income from coin sales (§ 10 [4] No 2). 
eral government has already decided on the method to calculate the budgetary structural adjustment it wants to use. This federal method is based on the one used by the European Commission (art. 109 [2] GG; § 5 [4] Law on $G G$ art. 115). Although the states can choose their method independently, constraints exist for those five states that get financial support. They had to agree to use the same procedure of structural adjustment as the federal government.

- Definition of extraordinary events: The states can decide to allow borrowing in case of natural catastrophes or extraordinary emergencies that originate outside the scope of public control and affect the state's budget considerably. In case of these events, the parliament must decide on a redemption plan organising the repayment of the extra debt in an adequate period of time (art. 109 [3] sentence $3 G G$ ).

- Comprehensiveness of budget definition: The states also have leeway in the precise definition of some of the crucial budgetary terms in the constitutional rule: The state's core budget just needs to consider payments to and income from special funds or state owned enterprises ( $\$ 18$ Law on Budget Principles, $H G r G$ ). However, a state can decide to include the budgets - thus new net borrowing - of special funds and state owned enterprises as well as those of the municipalities. As a result, there is an important dimension where state rules can make a substantive difference. Since the federal government does not consider "financial transactions", such as buying or selling liabilities or shares of enterprises for the calculation of its balance (art. 115 [2] sentence $5 G G$; $\S 3$ Law on $G G$ art. 115), a state could refer to this modification and claim it for itself, too.

If the states do not change their budgetary rules, the federal constitution's strict prohibition of no new net borrowing directly applies to the states (art. $31 G G$ ). However, the states are free to mirror the national rule in their constitutions or simple laws. Of course, they would also be able to go beyond the provisions of the Grundgesetz and to impose even stricter or more precise fiscal rules. Equally, they could shorten the transitory period towards a balanced budget. It is also worth mentioning that further room for state individualism exists with respect to the chosen democratic procedures for the establishment of a state rule. States could organise a referendum on a new state rule which might boost its democratic legitimacy and, hence, its political power (as was the case in Hesse).

Although the federal constitution's debt brake defines important new constraints for the state level, there is significant sub-national leeway. This corresponds with the autonomy of states under German federalism. Hence, it is of interest to analyse and measure sub-national heterogeneity in fiscal rules. 


\section{Function, Types and Impact of Fiscal Rules}

In general, it is the function of rules to commit political decision makers to a certain future policy and to overcome credibility problems. Such problems emerge if policy makers have an incentive to diverge from a pre-announced behaviour. ${ }^{9}$ Rational agents understand these incentives with the consequence that promises lack credibility and fail to impact on expectations. This problem can be virulent both for monetary policy (with respect to inflation targets and inflation expectations) and fiscal policy (with respect to deficit targets and expectations on fiscal sustainability). In principle, two ways are available to overcome time-inconsistency problems of elected politicians: The one applied for monetary policy is to hand over decision making to an independent institution, such as a central bank, whose decision-makers are expected to act less myopic than politicians facing re-election constraints. For budgetary policy, the standard solution is to implement rules that constrain fiscal decisions.

Two different types of budgetary rules can be distinguished: procedural budgetary rules and numerical fiscal rules. Von Hagen, Harden and Hallerberg have pioneered the analysis and the quantification of procedural rules, ${ }^{10}$ identifying several important details, such as a strong agenda-setting power of the finance minister, an early definition of binding budgetary objectives, limited power of the parliament for late budgetary amendments or fiscal transparency. ${ }^{11}$ According to this literature, ${ }^{12}$ two types of procedural rules can be successful to overcome the common-pool problem in budgetary decision making: ${ }^{13}$ Through a

9 Kydland, F.E./Prescott, E.E.: Rules Rather than Discretion. The Inconsistency of Optimal Plans, in: The Journal of Political Economy, 85/3 (1977), 473-492.

10 von Hagen, J.: Budgeting Procedures and Fiscal Performance in the European Communities, European Economy, in: Economic Papers, 96 (1992); von Hagen, J./Harden, I.J.: National Budget Processes and Fiscal Performance, European Economy Reports and Studies, 3 (1994), 311-418; von Hagen, J./ Harden, I.J.: Budget Processes and Commitment to Fiscal Discipline, in: European Economic Review, 39/3 (1995), 771-779; Hallerberg, M./von Hagen, J.: Electoral Institutions, Cabinet Negotiations, and Budget Deficits in the European Union, in: Poterba, J./von Hagen, J. (eds.): Fiscal Institutions and Fiscal Performance, Chicago, 1999, 209-232.

11 On fiscal transparency, see also: Wehner, J.: Legislatures and the Budget Process. The Myth of Fiscal Control, Basingstoke, 2010.

12 Hallerberg, M./Strauch, R./von Hagen, J.: The Design of Fiscal Rules and Forms of Governance in European Union Countries, in: European Journal of Political Economy, 23/2 (2007), 338-359.

13 The "common-pool problem" describes that very specific and targeted spending projects which benefit a small group are financed from the "common-pool" of today's and future tax revenues raised from all tax payers. This asymmetry is considered to create incentives for overspending and deficit spending. See Shepsle, K.A./Weingast, B.R.: Political Preferences for the Pork Barrel. A Generalization, in: American Journal of Political Science, 25/1 (1981), 96-111. 
"delegation approach" power is concentrated on a strong finance minister counterbalancing the particular interests of the other ministers, or, in employing a "contract approach", budgetary decision-making is constrained through early agreements within budgetary negotiations on overall general budgetary objectives.

Numerical fiscal rules which are at the focus of this analysis follow a different philosophy: They do not address the details of budgetary decision procedures but define certain numerical caps (e.g. on a maximum level of debt or deficit) in combination with implicit or explicit sanctions in case the cap is violated. The German constitutional debt brake with its deficit cap is a typical example of a numerical rule so that we concentrate in the following on indicators which have tried to capture the rigor of numerical fiscal rules. ${ }^{14}$

Overall, the evidence on the actual effects of numerical fiscal rules on budgetary outcomes tends to be favourable: ${ }^{15}$ According to the experience from federal states (United States, Canada, Switzerland) stricter rules correlate with lower debt and deficits. However, much of the older evidence suffers from methodological limitations. Already in 1996 Poterba has raised the question whether strict fiscal rules could not simply be a symptom of underlying conservative fiscal voter preferences. ${ }^{16}$ In this case, the correlation between strict rules and low deficits would not point at a causal link but would be driven by an omitted variable. The more recent literature has addressed this concern by explicitly taking fiscal preference proxies into account. With these refinements, undertaken for studies on fiscal rules of Swiss cantons, the results for the impact of rules are mixed: whereas Dafflon/Pujol cannot confirm a causal impact of fiscal rules, the results from Krogstrup/Wälti are more optimistic. ${ }^{17}$ As the literature is based on official budgetary data and cannot detect circumvention through creative accounting, there are limitations to this research. For the US states, von Hagen/Kiewiet and Szakaly find evidence that fiscal rules provoke creative ac-

14 Procedural fiscal rules have also been quantified through indicators, starting with von Hagen, J.: Budgeting Procedures, op.cit. For a more recent indicator, see Fabrizio, S./Mody, A.: Can Budget Institutions Counteract Political Indiscipline?, in: Economic Policy, 21/48 (2006), 689-739.

15 For a survey, see Krogstrup, S./Wälti, S.: Do Fiscal Rules Cause Budgetary Outcomes?, in: Public Choice, 136/1-2 (2008), 123-138.

16 Poterba, J. M.: Budget Institutions and Fiscal Policy in the U.S. states, in: American Economic Review, 86/2 (1996), 395-400.

17 Dafflon, B./Pujol, F.: Fiscal Preferences and Fiscal Performance: Swiss Cantonal Evidence, in: International Public Management Review, $2 / 2$ (2001), 54-78; Krogstrup, S./Wälti, S., op.cit. 
counting or debt shifting from the state to the municipal level. ${ }^{18}$

An alternative strategy to evaluate the impact of fiscal rules is to search for credibility effects in the pricing of government bonds. If investors have confidence that fiscal rules will be an effective constraint in the future, they might regard the respective jurisdiction's bonds as less risky compared to a jurisdiction without a strict rule. Indeed, there is evidence on the empirical relevance of this channel: Iara/Wolff studied the impact of fiscal rules on risk premia for the initial eleven euro area countries for the years 1999 to 2009. ${ }^{19}$ The authors made use of the European Commission's Fiscal Rule Index (FRI, see below). They did not find a significant direct effect of fiscal rules on risk spreads, but identified a significant impact while interacting the FRI with the general risk aversion of the financial markets. Thus, fiscal rules only have a negative effect on bond spreads in a market environment where risk sensitivity is high. Heinemann/Kalb/ Osterloh extended the approach from Iara/Wolff by including proxies for a country's stability culture to account for the omitted variable problem described above. $^{20}$ They asked whether fiscal rules simply reflect a country's risk preferences or whether they have a genuine impact. Their results point to the latter and to a particular potential of fiscal rules in countries with a historically low stability culture (measured e.g. on the basis of past inflation performance).

Overall, in the light of the empirical evidence a cautious optimism seems to be justified that strict fiscal rules can indeed have an impact on budgetary outcomes. Hence, as regards the German debt brake's target to eliminate deficits on a regular basis from 2020, it is important to know how states transpose the rule.

18 von Hagen, J.: A Note on the Empirical Effectiveness of Formal Fiscal Restraints, in: Journal of Public Economics, 44 (1991), 199-210; Kiewiet, D.R./Szakaly, K.: Constitutional Limits on Borrowing. An Analysis of State Bonded Indebtedness, in: Journal of Law, Economics and Organization, 12 (1996), 6297. Analogous studies exist for the impact of direct democracy on fiscal outcomes: Funk, P./ Gathmann, C.: Does Direct Democracy Reduce the Size of Government? New Evidence from Historical Data, 1890-2000*, in: The Economic Journal, 121/557 (2011), 1252-1280; Funk, P./Gathmann, C.: Voter Preferences, Direct Democracy and Government Spending, in: European Journal of Political Economy, 32 (2013), 300-319. Referenda are increasingly being used for German municipalities but are still rare at the state level. Furthermore, German direct democratic rules are characterized by a "fiscal taboo", i.e. voter initiatives must not relate to budget acts. See Asatryan, Z. et.al.: Direct Democracy and Local Public Finances under Cooperative Federalism, in: ZEW Discussion Paper No. 03-038, 2013.

19 Iara, A./Wolff, G.: Rules and Risk in the Euro Area, in: Bruegel Working Paper, 2011/10, Brussels.

20 Heinemann, F./Kalb, A./Osterloh, S.: Sovereign Risk Premia. The Link between Fiscal Rules and Stability Culture, in: Journal of International Money and Finance (forthcoming), 2014; Iara, A./Wolff, G., op.cit. 


\section{Quantifying the Strength and Credibility of Fiscal Rules}

Indexes which quantify the strength of a numerical fiscal rule try to capture to what extent this rule effectively constrains budgetary policies. Indexes may vary with regard to the categories chosen to analyse rules, what they measure and how precise, the weighting procedure, and how information on the categories is acquired.

In order to compare the stringency of national numerical rules across countries, two indexes have been developed by the European Commission and the International Monetary Fund (IMF). ${ }^{21}$ The EU's Fiscal Rule Index is built on two subindexes: the Fiscal Rule Coverage Index and the Index of Strength of Fiscal Rules. The first reflects the share of government expenditures covered by a rule. The second assesses the strength of this rule using five criteria: ${ }^{22}$ (1) the legal base of restrictions for changing the rule, (2) the degree of political independence of the body that is in charge of the monitoring, (3) the enforcement of the rule, (4) enforcement mechanisms, and (5) the media coverage of the rule. These criteria are weighted randomly using a complex procedure to define a range where the index value would most probably lie in. In order to calculate the Fiscal Rule Index the share of a rule indicated by the Fiscal Coverage Index is multiplied by the strength of the Fiscal Rule Index. The coding is based on a survey of government experts in the EU member countries.

The IMF index is based on seven scores: (1) enforcement, (2) coverage, (3) legal basis, (4) supranational rules, (5) monitoring and enforcement procedures, (6) flexibility, and (7) the average number of rules. ${ }^{23}$ The weighting is done using a principal component analysis.

These indexes serve as a starting point for our quantification of fiscal rules in the German federal states. However, neither the EU nor the IMF quantification procedure is applicable to the sub-national level in Germany without further qualification. The common national environment of German states precludes any variance for some of the sub-indexes. This holds, for example, for media attention in the case of the EU index, or for monitoring and enforcement in the case of both the IMF and EU index. Furthermore, these existing indexes are faced with some conceptual and methodological shortcomings: conceptually, the EU index con-

21 Directorate-General for Economic and Financial Affairs (DG ECFIN): Public Finances in EMU, European Economy, 3 (2006), 157ff..; International Monetary Fund: Fiscal Rules - Anchoring Expectations for Sustainable Public Finances, 2009.

22 Directorate-General for Economic and Financial Affairs (DG ECFIN), op.cit., 163f.

23 International Monetary Fund, op.cit., 8. 
siders the qualitative type of a rule, but not its numerical ambition (for example, budget balance rules limiting the deficit to $3 \%$ or to $10 \%$ of GDP are equally "good"). Methodologically, the self-assessment of civil servants in responsible ministries is an obvious source of distortion towards a too favorable assessment.

However, several criteria and elements of both indexes are helpful. We use them and create new ones to set up a specialised index to quantify the credibility of fiscal rules in the German federal states. Tab. 1 gives an overview of the index composition.

Our index is based on a two-dimensional approach. We differentiate between four parts of a rule and between five categories. For the first dimension, we use the distinction made by Schaltegger/Frey between four parts of a rule ${ }^{24}$ :

- The basic rule describes the aim of a budget rule, e.g. a balanced budget;

- Regulations describe details of this rule, how it should operate and to which parts of the budget it has to be applied;

- Relaxations describe conditions under which a state can deviate from the rule;

- Sanctions determine enforcement mechanisms to guarantee the implementation of the rule and to punish non-compliance.

With respect to the second dimension, we use five categories to describe the formal nature and the content of a rule. The aim is to mirror the credibility of a rule. The higher the credibility, the higher the scores assigned. Four categories assess formal characteristics and one category tries to capture the precision and stringency of the rule's content.

Categories A and B are adapted from the EU Fiscal Rule Index:

- Category A (legal base) assesses the legal background of a rule. The rating ranges from 1 to 4 where 4 is assigned for the strongest legal base. This is the one that can be changed the least easily.

Category B (enforcement mechanisms) indicates whether there are provisions guaranteeing enforcement and punishment in case of non-compliance. The rating ranges from 1 to 4 where 4 is assigned for mechanisms with the least political influence possible, as political decisions are likely to bias initial objectives according to current situations. ${ }^{25}$

24 Schaltegger, C.A./Frey, R.L.: Fiskalische Budgetbeschränkungen zur Stabilisierung öffentlicher Haushalte, in: Die Volkswirtschaft, 2 (2004), 16-19.

25 In contrast to this category used in the EU-Index, we do not assign an additional point for an escape clause, since we examine this in a special category. 
Table 1: Fiscal Rule Index for the German Federal States

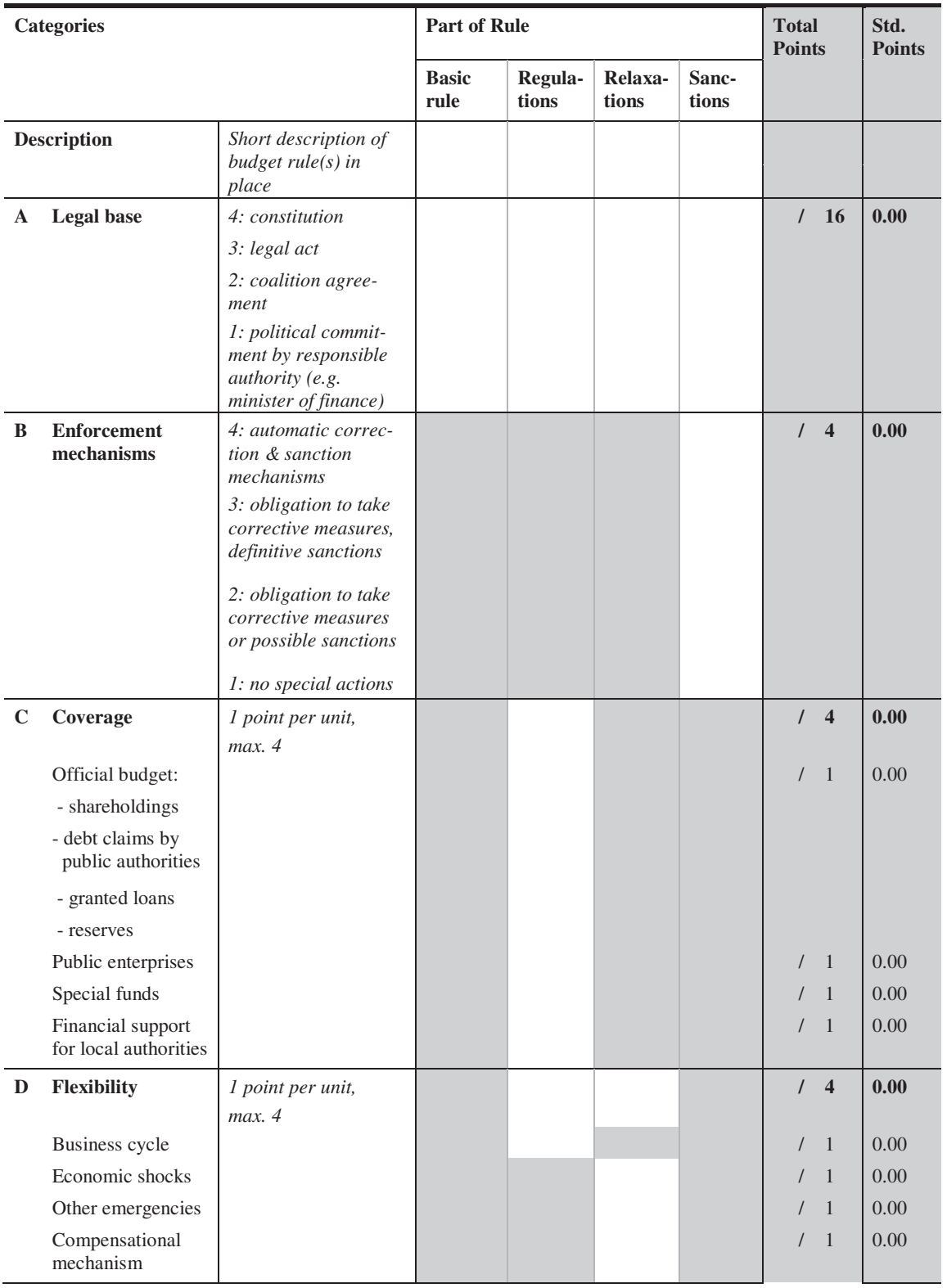




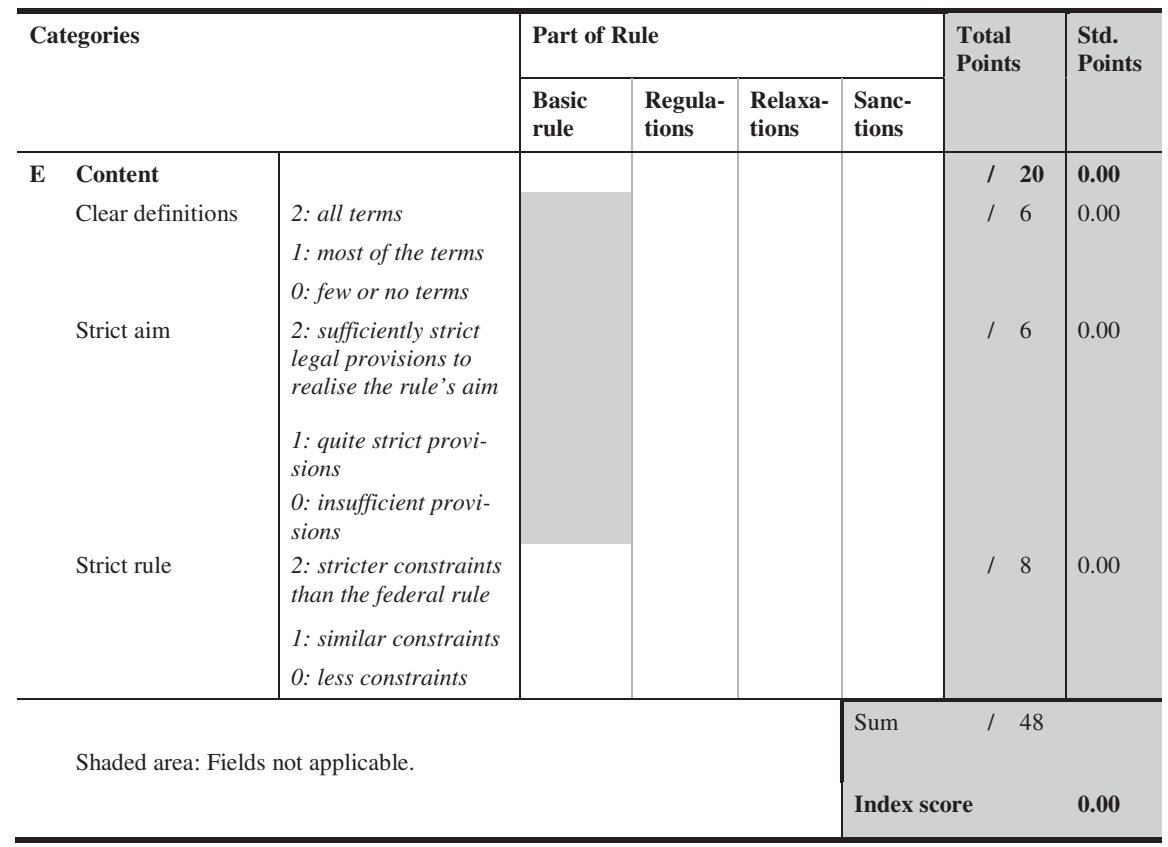

Source: Own calculation.

Category $\mathrm{C}$ is based on the underlying idea of the EU Fiscal Rule Coverage Index. It tries to assess the part of government expenditures that is covered by a budget rule. The more complete the coverage of expenditures, the less opportunities exist to circumvent the rule by shifting expenditures from a covered to a noncovered part. However, in the adoption of this category, we do not follow the EU index' example which uses the share of total expenditure covered. This share might be vulnerable to strong changes over time. The problem is that the expenditure share may rather quantify the effects of a rule rather than its content. For example, expenditures for establishing a special fund in one year might decrease the ratio of coverage, but the score will increase in the next year although the rule did not get "better". Therefore, we set up another measure to assess the degree of coverage which is a count variable adding up the types of public expenditure covered by the rule:

- Category C (coverage) is calculated as a count variable which adds 1 point for each of the following kinds of total government budget which is covered by the fiscal rule under scrutiny: the official state budget (as decided by parliament), state owned enterprises, special funds and financial support for local authorities. Thus, the rating ranges from 1 (only official state budget covered) to 4 (total government expenditures covered). 
Category D is inspired by the IMF index score for flexibility. To be credible a rule needs to be flexible to a certain degree. Otherwise one would expect the government to break or the legislative to change the rule as soon as compliance is not possible anymore.

- Category D (flexibility) considers three cases of flexibility: first, a continuous cyclical adjustment; second, provisions for exceptional economic shocks; and third, other emergencies, such as catastrophes outside of the scope of the government's control. Finally, compensational mechanisms, for example through a redemption plan, are an important precaution to limit the dangers of flexibility provisions and to commit the budgetary authorities to correct the exceptional build-up of public debt. 1 point is assigned for each of the three flexibility cases and for the existence of a well-defined compensational mechanism.

Categories A to D do not yet evaluate a fiscal rule's precise contents. In order to examine its content, its precision and its stringency we construct category E.

- Category E (content) consists of three parts. The first, clear definitions, examines whether key terms of the rule are clearly defined by law. Vague formulations must then be defined within the day-to-day budgetary decision making or the judiciary and therefore let a large scope for interpretations and, hence, are more vulnerable to manipulations. If more than one third of the key terms are clearly defined, 1 point is assigned. If there are less, 0 points and if there are more than two-thirds, 2 points are assigned.

The second part, strict aim, examines whether regulations, relaxations and sanctions of a budget rule are sufficiently strict to meet the aim laid down in the basic rule. Here, we qualitatively judge the content of a rule. If, for example, the flexibility clauses - although existent and clearly defined - allow deviations too often, it is hardly possible that the basic rule is followed regularly. ${ }^{26}$ The rating ranges between 0 - no strict regulations - and 2 - regulations that are strict enough.

The third part, strict rule, tries to judge the ambition of the rule. Taking the provisions of the federal debt brake as a reference point, the score ranges from 0 to 2 . A rule that is as strict as the federal rule gets 1 point. A rule that is even stricter gets 2 , a rule that is less strict 0 points. This measure takes into account that states could want to implement a stricter rule. Hereby, we

26 Category $D$ only assesses whether there are flexibility clauses. We consider them as a necessary part of a budget rule because they guaranty a certain stability of the budget rule. If there were no flexibility clauses, the budget rule would probably be changed during an economic shock. However, the flexibility clauses should not allow for too much flexibility; the budget rule must be applied in "normal times" to remain credible. Thus our indicator covers the full trade-off of flexibility: on the one hand a rigid rule is not credible, on the other flexibility must not lead to arbitrariness. 
can account for the quality of a rule without falling to normative judgements of "good" or "bad". The points assigned to each of the three parts sum up to the rating of category $\mathrm{E}$.

In order to follow the construction of the index' score precisely, we first examine each of the four parts of a rule separately. All points of a category sum up across all parts and are translated into a percentage value. The mean of the percentage values of all categories form the index score.

We would like to stress that this approach at quantification can be applied to a state rule independently from its specific type, i.e. whether the rule refers to the budget balance, the stock of debt or the level of expenditure. ${ }^{27}$ In any case where a state has installed a combination of these different types we assess their joint operation since these rules interact and complement each other.

Overall, the index is supposed to cover the dimensions which affect the credibility of fiscal rules. Of course, this index suffers from the usual caveats of index construction: the weighting is somehow arbitrary and while some index points can be assigned quite objectively, for others the assessment implies some subjectivity.

\section{The German States' Fiscal Rules: Description and Quantifica- tion}

The following chapter describes the states' budget rules in detail ${ }^{28}$ and quantifies the index value for each of them applying the above defined method. ${ }^{29}$ All states base their budget laws on their constitution and state budget regulations (Landeshaushaltsordnung, LHO). The constitution is more difficult to change than the LHO which can be changed by simple majority. None of the states disposes of specific sanctions for the budget rule. A parliamentary minority can take the budget plan - as every other bill - to the Constitutional Court, but this is no

27 The indexes of the EU (DG ECFIN, 2006: 151) and the IMF (International Monetary Fund, 2009: 5f.) differentiate between: a budget balance rule which determines a limit to the budget balance; a debt rule which targets the stock of debt that has been accumulated up until a certain date; an expenditure rule which limits the amount of expenditures or the growth of expenditures; a revenue rule which limits either the whole revenue magnitude or certain parts of it, e.g. tax income. Revenue rules currently do not play a role in German states.

28 For more information on an earlier qualitative assessment of the states' transpositions of the federal debt rule see: German Council of Economic Experts: Verantwortung für Europa wahrnehmen, Jahresgutachten 12, 2011.

29 An exemplary detailed construction sheet for Baden-Württemberg can be found in the Appendix, the full set of state sheets is available here: www.zew.de/zse_fri13. 
"automatic" mechanism forcing the parliament to comply with the rules. Only states that receive financial support according to the KonsHilfG face the sanction of a cut-off from the support in case of non-compliance. This is considered to be an automatic mechanism but covers only a very small part of the budget. Furthermore, the states need to comply with the Budget Principles Act (Haushaltsgrundsätzegesetz, $H G r G$ ). This act prescribes how the budget is to be designed and specifies the calculation of the term "budget". However, the states are free to implement stricter rules. We also consider declarations of intent in the mid-term financial plans, coalition agreements or similar documents but we do not take budget projections into account as they reflect the current economic and financial situation and not necessarily political intentions.

\section{Baden-Württemberg (BW)}

Already in 2007, Baden-Württemberg got a stricter budget rule by law (LHO), but it got changed again in 2012. The constitution remained unchanged up until now. The balanced-budget rule is very close to the new federal rule. The budget must be balanced without borrowing "in principle" (LHO art. 18 [1]). Until 2019, borrowing is allowed but in yearly decreasing amounts ( $\mathrm{LHO}$ art. 18 [2]). However, higher borrowing is possible in case of business cycle developments ( $\mathrm{LHO}$ art. 18 [3] and [4]) and of natural catastrophes or similar severe emergencies ( $\mathrm{LHO}$ art. 18 [6]). If these exceptions come into use, parliament must decide a redemption plan ( $\mathrm{LHO}$ art. 18 [6]). Actual amounts of borrowing are recorded on a "control account" that needs to be kept in narrow boundaries ( $L H O$ art. 18 [5]). Furthermore, the coalition agreement ${ }^{30}$ sets out the target to use additional tax income for debt redemption.

The restrictions are strict and the terms are specified. However, exceptions to the principle of a balanced budget could be used extensively. The control account's boundaries are quite large and a simple majority of the parliament can decide a redemption plan that does not need to cover a specific but only "appropriate" time span. The rules do not apply to state owned enterprises, special funds (constitution art. 79, $\mathrm{LHO}$ art. 26 [2]) or recipients of grants ( $\mathrm{LHO}$ art. 26 [3]). The index score is 0.62 .

30 Bündnis90/DIE GRÜNEN, SPD: Der Wechsel beginnt. Koalitionsvertrag, Baden-Württemberg 20112016, Stuttgart, 2011. 


\section{Bavaria (BY)}

Already in 2006, the state budget regulations (BayHO, simple law) got changed, and again in 2012. In 2013, the constitution was changed by referendum. The constitution's new rule first applies in 2020, whereas the less strict rule in the BayHO already applies in 2013. However, until 2019 the old constitutional's role "may" be used; it is similar to the former federal rule (investment-rule).

The new budget balance rule prescribes that the budget must be balanced without borrowing respecting business cycle fluctuations (BayHO art. 18 [1]). Borrowing is allowed to respond to "demands of the macroeconomic equilibrium" or similar severe situations. The maximal amount must not exceed the sum of expenditures for investments. Higher borrowing is possible in case of a "disturbance of the macroeconomic equilibrium" (BayHO art. 18 [2]). Furthermore, the debt stock needs to be reduced to zero up until 2030 (BayHO art. 18 [1]).

The constitution's new rule catches up the principle and business cycle adaptions of the current BayHO's rule but narrows the exceptions: In case of natural catastrophes or similar severe emergencies borrowing according to the investmentsrule is allowed, but the parliament must decide a respective redemption plan for an adequate time span (constitution art. 82 [1] and [2]).

Key terms ("investments" [ $L H O$ art. 13 (3) No 2 sentence 2, same as in $H G r G$ ], adaption to the "business cycle", "demands" and "disturbance of the macroeconomic equilibrium") of the current as well as the future rule are poorly defined. However, the future rule defines exception clauses and prescribes a redemption plan. The aim of eliminating the debt stock at all is quite strong, but it lacks implementation. The current rule's index score is, as a result, 0.48, from 2020 onwards 0.66 .

\section{Berlin (BE)}

Berlin did not change its budget rule by laws, yet. It is similar to the former federal budget rule. However, there are a number of restrictions that the government imposed on itself. Until 2019, Berlin is also subject to strict budget regulations in exchange for public financial support.

Berlin has a budget balance rule. Borrowing is only allowed if other financial means are not "available" (constitution art. 87 [2]). The amount of borrowing must not exceed the amount of expenditures for investments. Higher borrowing is allowed to respond to a "disturbance of the macroeconomic equilibrium" (con- 
stitution art. 87 [2]). The parliament must determine that a disturbance exists and that borrowing would help to repel it ( $\mathrm{LHO}$ art. 18 [1]). Since Berlin gets financial support according to the KonsHilfG, it is obliged to decrease its deficit to zero, at the latest in 2020 (VV KonsHilfG). If Berlin does not comply with these limits and in case there is no "exceptional situation" approved by the Stability Council, financial support is cut off ( $V V$ KonsHilfG art. 6). Furthermore, the government aims at cutting new net borrowing to zero by 2016 and obliges itself to use unexpected additional financial means for debt redemption and balance an unexpected increase in expenditures in one section by the respective amount of a decrease in expenditures in another. ${ }^{31}$ Moreover, the government aims to limit the yearly general growth of expenditures by $0.3 \% .^{32}$

Berlin's budget rule as laid down in laws is hardly credible. Borrowing is allowed as long as other financial means are not available. Thus, no reasons must be given to borrow and it is not limited, since "investments" are not specifically defined ( $\mathrm{LHO}$ art. 13 [3] No 2 sentence 2, same as in $\mathrm{HGrG}$ ). Also, the term "disturbance of the macroeconomic equilibrium" is undefined and the terms "additional income", "additional expenditures" and "expenditures" are poorly specified. The rule does not consider special funds, state owned enterprises and recipients of grants ( $\mathrm{LHO}$ art. 26). The $V \mathrm{~V}$ KonsHilfG is much more explicit and helps Berlin to gain credibility: If the government does not follow definite numerical deficit limits, the support is cut off. Thanks to the provisions in the $V V$ KonsHilfG Berlin gets an index score of 0.65 . However, the financial support ends in 2019 and then the index score will - if nothing changes - fall back to 0.46 in 2020 .

\section{Brandenburg (BB)}

Brandenburg does not have similar legal provisions, yet. The budget rule in Brandenburg is similar to the former federal rule. Borrowing is allowed up to the amount of expenditures for investments (constitution art. 103 [1] sentence 2). Hereby, the budget must consider "demands of the macroeconomic equilibrium" and the "protection of natural living conditions of present and future generations" (constitution art. 101 [1]). Higher borrowing is allowed to respond to a "disturbance of the macroeconomic equilibrium" (constitution art. 103 [1] sen-

31 SPD, CDU: Koalitionsvereinbarung, Berliner Perspektiven für starke Wirtschaft, gute Arbeit und sozialen Zusammenhalt. Koalitionsvereinbarung für die Legislaturperiode 2011-2016, Berlin, 2011.

32 SPD, CDU: Koalitionsvereinbarung, op.cit. 
tence 3). The parliament must decide that a disturbance exists and that borrowing would help to repel it ( $\mathrm{LHO}$ art. 18 [1]).

Key terms ("investments", "macroeconomic equilibrium", its "demands" and "disturbance") are not specified. However, Brandenburg defines the term "investments" more precise as expenditures that "maintain, extend or improve means of production of the whole economy" ( $V V$-HS 3.2.1.1, LHO art. 13 [3] No 2 sentence 2). The rule does not consider special funds, state owned enterprises or recipients of grants (constitution art. 101 [2], LHO art. 26). However, in the current mid-term financial plan, ${ }^{33}$ the government declares to aim at cutting new net borrowing to zero by 2016 . The budget should be balanced in the upcoming years and debt should be paid back in economically good times. The index score is 0.51 .

\section{Bremen (HB)}

Bremen's rule is still similar to the former federal budget rule. It is complemented by a budget balance rule according to the $V V$ KonsHilfG. Borrowing is allowed up to the amount of expenditures for investments (constitution art. 131a sentence 2) and higher borrowing in case of a "disturbance of the macroeconomic equilibrium" (constitution art. 131a sentence 2). The terms "investments" ( $\mathrm{LHO}$ art. 13 [3] No 2 sentence 2, same as in $\mathrm{HGrG}$ ), "macroeconomic equilibrium" and its "disturbance" are not specified. Also, the rule does not consider borrowing by special funds, state owned enterprises and recipients of grants (LHO art. 26). According to the KonsHilfG, Bremen has to comply with decreasing structural deficit limits ( VV KonsHilfG art. 4). If it does not and if there is no "exceptional situation" approved by the Stability Council, financial support is cut off ( VV KonsHilfG art. 6). The current index score is 0.64 but will fall back to 0.45 in 2020 when the financial support ends.

\section{Hamburg $(\mathrm{HH})$}

From 2013 on, Hamburg's constitution prescribes a continuous reduction of the structural deficit until 2019. The Financial Framework Law prescribes numerical limits for adjusted expenditures and additional income that need to be followed. A decrease in income must result in a decrease in expenditures, but, vice versa, an increase in income could lead to an increase in expenditures and, hence, does 
not need to be used for debt redemption. Besides that, the current rule is close to the former federal rule and allows borrowing up to the amount of expenditures for investments (constitution art. 72 [1], LHO art. 18 [1]). Exceptions can be made in case of "extraordinary demands" (constitution art. 72 [1]), more specifically in case the "macroeconomic equilibrium" is disturbed ( $\mathrm{LHO}$ art. 18 [1]). The rule's index score is 0.47 .

The new rule prescribes a balanced budget "in principle" from 2020 onwards. Thereby the business cycle has to be taken into account. The parliament's twothirds majority can approve higher borrowing in case of natural catastrophes or extraordinary emergencies but needs to decide on a respective redemption plan at the same time (constitution art. 72 new). In contrast to the old rule, the new one is strict. The use of exceptions has a high parliamentarian threshold. However, the rule does not apply to special funds, state owned enterprises and recipients of grants (LHO art. 26). The new rule's index score is 0.67 .

\section{Hesse (HE)}

In 2011, Hesse's constitution got amended by referendum in favour of a debt rule similar to the new federal rule. The new rule first applies in 2020 (constitution art. 161). In 2013, parliament decided on a new law implementing art. 141 of the constitution. It specifies the constitution's rule in detail and will replace the current rule and respective $L H O$ articles from 2015 on. The current rule is close to the former federal rule and allows borrowing up until the amount of expenditures for investments ${ }^{34}$ and beyond that in case of "extraordinary demands" (constitution art. 141). The index score for this rule is 0.50 .

The rule that comes into force in 2015 prescribes a balanced budget without borrowing "in principle" (law implementing art. 141 of the constitution art. 1[1]). Borrowing is allowed to respond to business cycle fluctuations but must be balanced symmetrically as recorded on a control account. That account should not exceed $5 \%$ of the tax income's average of the last 3 years. Additional tax income should be used for general debt redemption or reserves. Higher borrowing is only allowed in case the parliament's two-thirds majority declares the existence of a natural catastrophe or an extraordinary emergency and at the same time decides a redemption plan of max. 7 years. Also, the amount of borrowing in 2014 is to be reduced yearly until 2019.

34 The constitution uses the term "advertising ends" (constitution art. 141) which means quite the same as "investments". 
The provisions of the current rule are vulnerable to manipulation, because key terms are not specified ("investments" [ $\mathrm{LHO}$ art. 13 (3) No 2 sentence 2, same as in $H G r G$ ] and "extraordinary demands"). The new rule is more precise. The basic rule as well as its regulations and exception clauses are specified. However, the rule does not consider debt claims by public authorities (law implementing art. 141 of the constitution [1]), special funds, state owned enterprises and recipients of grants ( $\mathrm{LHO}$ art. 26). The index of this rule is 0.62 .

From 2020 on, this rule (balanced "in principle", "symmetric" business cycle adaption, exceptions for natural catastrophes and extraordinary emergencies, redemption plan) is backed by the constitution which makes it a lot stronger (constitution art. 141 new). This raises the index score to 0.65 .

\section{Lower Saxony (NI)}

Lower Saxony changed its $L H O$ in 2012, the new rule comes into force from 2017 on. The current rule is close to the former federal rule. Borrowing is allowed up until the amount of expenditures for investments and debt conversion (constitution art. 71 sentence 2). Exceptions are allowed to respond to a "disturbance of the macroeconomic equilibrium" or to an "immediate threat to the natural living conditions" (constitution art. 71 sentence 3). The parliament must define a situation as exceptional and make clear that borrowing would help to repel it ( $\mathrm{LHO}$ art. 18 [1]) as well as decide on a redemption plan (LHO art. 18a [3]). Key terms ("investments" [ $\mathrm{LHO}$ art. 13 (3) No 2 sentence 2, same as in $H G r G$ ), "macroeconomic equilibrium", its "disturbance" and "immediate threat to the natural living conditions") are not specified. The rule does not consider special funds, state owned enterprises and recipients of grants ( $\mathrm{LHO}$ art. 26). However, from 2014 on borrowing must be reduced along decreasing numerical limits ( $L H O$ art. 18a [1] and [2]). The index score is 0.55. From 2017 on, the investments-rule does not apply anymore and the budget must be balanced "in principle" (LHO art. 18a [1]). This raises the index score to 0.57 .

\section{Mecklenburg-West Pomerania (MV)}

The parliament of Mecklenburg-West Pomerania implemented a new budget rule in the constitution in 2011. It will first apply in 2020 (constitution art. 79a). The LHO is not renewed, yet.

The current rule is similar to the former federal debt rule: borrowing is allowed up to the amount of expenditures for investments and beyond that in case of a 
"disturbance of the macroeconomic equilibrium" or an immediate threat to the "economic and labour market development". The parliament has to justify the use of exceptions by defining the situation as exceptional and clarifying that borrowing would help to repel it (constitution art. 65 [2]). This rule's index score is 0.46 .

According to the new rule (constitution art. 65 [2]), the budget must be balanced without borrowing "in principle". Exceptions are allowed to respond to business cycle fluctuations in a "symmetric" way. These situations must be compared to several similar situations years ago. Exceptions can also be made to respond to natural catastrophes or exceptional emergencies that lie outside the scope of control of the state and affect the budget considerably. In both cases, the parliament must simultaneously set up a redemption plan that regulates paying back the debt in an "appropriate" period of time.

The current rule is vulnerable to exploitations. Key terms ("investments" [ $\mathrm{LHO}$ art. 13 (3) No 2 sentence 2, same as in $H G r G$ ), "macroeconomic equilibrium", its "disturbance" and a threat to the "economic and labour market development") are not specified. The rule does not consider special funds, state owned enterprises or recipients of grants ( $\mathrm{LHO}$ art. 26). The new rule does not consider them either, but is stricter regarding the use of exception clauses and prescribes a redemption plan. Although the term "appropriate" does not define a concrete period of time, the term helps to appeal the budget. The new LHO should define the term "business cycle" and how the adaption can be made "symmetrically". The new rule's index score is 0.64 .

\section{North Rhine-Westphalia (NW)}

North Rhine-Westphalia's budget rule is similar to the former federal rule. Borrowing is allowed to respond to "demands of the macroeconomic equilibrium". On a "regular basis" borrowing must not exceed the amount of expenditures for investments (constitution art. 83 sentence 2). Higher borrowing is allowed in order to respond to a "disturbance of the macroeconomic equilibrium" ( $\mathrm{LHO}$ art. 18 [1]). In this case the parliament must define that the disturbance exists and that borrowing would help to repel it ( $\mathrm{LHO}$ art. 18 [1]). The rule is not strict, since key terms ("investments" [ $L H O$ art. 13 (3) No 2 sentence 2, same as in $H G r G]$, "macroeconomic equilibrium", its "demands" and "disturbance") are not specified. Also, the rule does not consider special funds, state owned enterprises and recipients of grants ( $\mathrm{LHO}$ art. 26). The index score is 0.45 . 


\section{Rhineland-Palatinate (RP)}

In 2010, Rhineland-Palatinate's parliament decided to implement a similar rule in its constitution, followed by respective simple laws in 2012. The new rule applies in 2012; however, until 2019 the old role "may" be used. The old rule is similar to the former federal rule: borrowing is allowed up until the amount of expenditures for investments. Exceptions can be made in order to respond to a "disturbance of the macroeconomic equilibrium" (constitution art. 117 sentence 2). The parliament must declare a situation as exceptional and give reasons that borrowing would help to repel it ( $\mathrm{LHO}$ art. 18 [1]).

The new budget balance rule prescribes that the budget plan must be balanced without borrowing (constitution art. 117 [1]). This refers to the "structural" budget (law on art. 117 of the constitution, LHO art. 18), thus reducing the overall budget by i.a. financial transactions, business cycle developments, reserves for the pension funds and state owned enterprises. Differences between the planned and the actual budget are recorded on a control account. It must be balanced over time and should not exceed its lower limit as of $15 \%$ of the tax income, which is a significant margin. Exceptions are allowed in case of natural catastrophes or similar severe emergencies and to adapt - at most within four years - to changes of budget affecting laws (constitution art. 117 [1] sentence 2 No 2). The parliament must declare a situation as exceptional (constitution art. 117 [1] sentence 3) and simultaneously decide a redemption plan (constitution Art. 117 [1] sentence 4). The budget rule should consider liabilities of state owned enterprises, special funds and recipients of grants (constitution art. 117 [3], law on art. 117 of the constitution); however, the structural budget does not take state owned enterprises into account. Nonetheless, the broad coverage of the public sector is outstanding among German federal states.

Whereas the old rule is vulnerable to manipulation since key terms ("investments" and "disturbance of the macroeconomic equilibrium") are not specified, the new rule hardly is, because it is very strict. The structural deficit and the adaption to the business cycle are specified. The new rule clearly defines exception clauses and prescribes a redemption plan. Contrarily to the new rule, the old one does not consider special funds, state owned enterprises and recipients of grants ( $\mathrm{LHO}$ art. 26). Since the old rule "may" be used as an exception to the new one, the index score is 0.69 . 


\section{Saarland (SL)}

Saarland still does not have a new budget rule. Since it gets financial support according to the KonsHilfG, it must follow strict deficit limits. The current rule is similar to the former federal rule: Borrowing is allowed up to the amount of expenditures for investments (constitution art. 108 [2]). Exceptions are possible to respond to a "disturbance of the macroeconomic equilibrium" or in case of "extraordinary demands" (art. 108 [2]). The parliament must define a situation as exceptional and make clear that borrowing would help to repel it (art. 18 [1]). If the parliament borrows to respond to "extraordinary demands", it needs to decide a redemption plan ( $\mathrm{LHO}$ art. 18 [1] sentence 3). Furthermore, Saarland must reduce its deficit along numerical limits to zero until 2020 (VV KonsHilfG art. 4). The concrete calculation of this deficit is determined in the VV KonsHilfG ( $V V$ KonsHilfG art. 2 [1]). If Saarland does not comply with these limits and if there is no "exceptional situation" approved by the Stability Council, financial support is cut off (VV KonsHilfG art. 6).

Thanks to the provisions of the VV KonsHilfG, Saarland's budget rule gained credibility: Key terms are defined, a third body monitors the enforcement and sanctions are possible. However, key terms of Saarland's original rule ("investments" [LHO art. 13 (3) No 2 sentence 2, same as in $H G r G$ ], "disturbance of the macroeconomic equilibrium" and "extraordinary demands") are not specified. Also, the time span the redemption plan must cover is not defined. The rule does not consider special funds, state owned enterprises or recipients of grants ( $\mathrm{LHO}$ art. 26). The current index score is 0.70 , but will - if nothing changes - fall back to 0.57 in 2020 when financial support ends.

\section{Saxony (SN)}

Already in 2008, Saxony implemented a stricter budget rule in the LHO. The constitution was changed in 2013, coming into effect from 2014 on. Saxony uses a combination of a balance budget and a debt rule. The budget must be balanced without borrowing (constitution art. 95 [2]), and the debt stock must not exceed the level of 2008 ( $\mathrm{LHO}$ art. 18 [1]). Borrowing is allowed only if the amount of tax income deviates from a 4 year-average and only up to $99 \%$ of this average (constitution) while the debt stock level of 2008 should not be exceeded permanently ( $L H O$ art. 18). At the same time, the parliament's simple majority needs to decide upon respective debt redemption within eight years. Accordingly, additional tax income must be used for debt redemption (constitution art. 95 [4]). 
Higher borrowing is only allowed if the parliament's two-thirds majority (simple majority for LHO's DR) states the existence of a natural catastrophe or extraordinary emergency (whose origin lies outside the state's scope of control and affects the state's finances considerably) and a redemption plan covering at maximum eight years. Borrowing exceeding the debt stock is only allowed if tax income decreases by $3 \%$ from one year to another and must be accompanied by a 5 year redemption plan ( $\mathrm{LHO}$ art. 18). Saxony's rule is two-fold and hence quite strict. Key terms ("business cycle adaption", "natural catastrophes" and "similar severe situations") are well defined, the balanced budget and debt stock limits are sharp as well as the requirements for debt redemption. High borrowing requires the approval of a two-thirds majority in the parliament. Although the rule covers special funds, it excludes one of the biggest fund, the one for pensions (constitution art. 95 [7]), and does not consider state owned enterprises and recipients of grants ( $L H O$ art. 26). The index score is 0.76 .

\section{Saxony-Anhalt (ST)}

In 2010, the parliament changed the $L H O$ to implement a stricter budget rule the constitution remained unchanged. Since Saxony-Anhalt receives financial support according to the KonsHilfG, it must follow strict deficit limits. The budget plan must be balanced without borrowing (art. 18 [1]). Exceptions are allowed in order to adapt to serious business cycle fluctuations, natural catastrophes or extraordinary emergencies that elude the scope of the state's control (art. 18 [2]). Simultaneously, the parliament must approve a redemption plan that prescribes the repayment in an "appropriate" scope of time (art. 18 [3]). Additionally, the debt stock must decrease regularly (art. 18 [4]). Furthermore, Saxony-Anhalt must reduce its deficit along numerical limits onto zero until 2020 (VV KonsHilfG art. 4). The concrete calculation of this deficit is determined in the VV KonsHilfG (VV KonsHilfG art. 2 [1]). If Saxony-Anhalt does not comply with these limits and if there is no "exceptional situation" approved by the Stability Council, financial support is cut off (VV KonsHilfG art. 6).

All rules taken together constrain the financial scope of the parliament considerably. The VV KonsHilfG specifies the terms "balanced budget" and "business cycle developments". The requirement to decrease the debt burden continuously limits possible exploitations. However, the time span of a redemption plan is not defined and the rule does not consider special funds, state owned enterprises or recipients of grants ( $\mathrm{LHO}$ art. 26). The index score is 0.77 but will fall back to 0.64 in 2020, when financial support has ended. 


\section{Schleswig-Holstein (SH)}

In 2010, Schleswig-Holstein's parliament decided to implement a stricter rule in the constitution which would be binding from 2020 on. In 2012, parliament passed a respective law implementing art. 53 of the constitution. SchleswigHolstein receives financial support according to the KonsHilfG and, therefore, must comply with decreasing deficit limits until 2020 (VV KonsHilfG).

The current rule is a budget balance rule. "In principle" the budget must be balanced without borrowing (constitution art. 53 [1]). Borrowing is allowed in order to respond to business cycle fluctuations in a "symmetric" way (constitution art. 53 [2], detailed prescriptions in the implementation law $\S 1$ ). In case of natural catastrophes or extraordinary emergencies that lie outside the scope of the state's control and that affect the budget considerably, borrowing is possible if twothirds of the parliament's members agree. Simultaneously, they must determine a redemption plan that prescribes the repayment of the debt within an "appropriate" scope of time (constitution art. 53 [3]). Deviations from the planned and the implemented budget will be noted on a "control account" (implementation law $\S$ 8). If the accounting balance exceeds a specific threshold it must be reduced, but with respect to the business cycle. Thereby, Schleswig-Holstein was the first state that mirrored the federal level's control account. Transitional provisions between 2011 and 2019 allow borrowing up to yearly decreasing limits ${ }^{35}$ (constitution art. 59a [1]). These regulations go in line with the VV KonsHilfG (art. 2 [1] and [4]). If Schleswig-Holstein does not comply with these limits and if there is no "exceptional situation" approved by the Stability Council, financial support is cut off (VV KonsHilfG art. 6).

The budget rule is strict: All regulations are implemented in the constitution, most of the key terms are defined ("in principle" considers the named exceptions, "budget" means the structural balance as defined in the VV KonsHilfG, "natural catastrophes" and "extraordinary emergencies" must be defined by twothirds of the parliament's members) and there are strict deficit limits. However, it is not yet specified how a "symmetric" adaption to business cycle developments would work. The rule does not consider special funds, state owned enterprises (constitution art. 50 [1]) and recipients of grants ( $\mathrm{LHO}$ art. 26). The index score is 0.77 but will fall back to 0.66 in 2020, when financial support has ended.

35 The limits target the structural deficit from 2010 on. The limit for one year decreases by $10 \%$ compared to the preceding year. 


\section{Thuringia (TH)}

In 2009, the parliament decided to implement a stricter debt rule in the LHO the constitution remained unchanged. The budget must be balanced without borrowing ( $\mathrm{LHO}$ art. 18 [1]). If the total income is less than the average of the last three years, borrowing is allowed up to the amount of income the budget plan had foreseen. Higher borrowing is allowed in case of natural catastrophes or extraordinary emergencies ( $\mathrm{LHO}$ art. 18 [2]). Simultaneously, the parliament must decide a redemption plan that prescribes the repayment within five years ( $\mathrm{LHO}$ art. 18 [3]). Additionally, expenditures for the personnel must not exceed $40 \%$ of the total expenditures (constitution art. 98 [3]). Furthermore, additional income must be used for debt redemption (budget law 2013/2014). The rule is strict: Borrowing is constrained and redemption is mandatory. However, the rule does not consider special funds, state owned enterprises and recipients of grants ( $\mathrm{LHO}$ art. 26). The index score is 0.66 .

\section{Comparison}

There is a significant variance in the strength of budget rules among the German federal states according to our index quantification. The index scores range between 0.45 and 0.77 . The table below displays all index scores.

Currently, Schleswig-Holstein (0.77) and Saxony-Anhalt (0.77) posses the strongest rule, followed by Saxony (0.76). The first two states receive financial support. Saarland, that also receives financial support (0.70), and RhinelandPalatinate (0.69) range in the upper half. In contrast, from 2020 on, when the support is cut off, the recipient states score mostly in the lower half - except for Schleswig-Holstein (0.66) and also Saxony-Anhalt (0.64), which already implemented a stricter budget rule. The temporary relative strength of these states is explained by the fact that they face fiscal sanctions in the period up to 2020. This threat results from the conditionality of the financial consolidation support and ends with these payments in 2019.

At present, North Rhine-Westphalia (0.45) and Mecklenburg-West Pomerania (0.46) put forward the weakest rule of all states, closely followed by Hamburg (0.47), Bavaria (0.48), Hesse (0.50) and Brandenburg (0.51). Until now, all these states developed rules similar to the former federal rule. They differ only because of more or less specified key terms. 
Table 2: Index scores of the German federal states

\begin{tabular}{|c|c|c|c|c|c|}
\hline $\begin{array}{l}\text { Federal } \\
\text { State }\end{array}$ & Current Rule & $\begin{array}{l}\text { KonsHilfG- } \\
\text { recipient }\end{array}$ & $\begin{array}{l}\text { Federal } \\
\text { State }\end{array}$ & Future Rule ${ }^{1}$ & $\begin{array}{l}\text { KonsHilfG- } \\
\text { recipient }\end{array}$ \\
\hline ST & 0.77 & $*$ & SN & 0.76 & \\
\hline SH & 0.77 & $*$ & $\mathbf{R P}$ & 0.69 & \\
\hline SN & 0.76 & & НH & 0.67 & \\
\hline SL & 0.70 & $*$ & BY & 0.66 & \\
\hline RP & 0.69 & & SH & 0.66 & $*$ \\
\hline TH & 0.66 & & TH & 0.66 & \\
\hline $\mathbf{B E}$ & 0.65 & $*$ & $\mathrm{HE}^{2}$ & 0.65 & \\
\hline HB & 0.64 & $*$ & MV & 0.64 & \\
\hline BW & 0.62 & & ST & 0.64 & $*$ \\
\hline NI & 0.55 & & BW & 0.62 & \\
\hline BB & 0.51 & & NI & 0.57 & \\
\hline $\mathrm{HE}^{2}$ & 0.50 & & SL & 0.57 & $*$ \\
\hline BY & 0.48 & & BB & 0.51 & \\
\hline HH & 0.47 & & $\mathbf{B E}$ & 0.46 & $*$ \\
\hline MV & 0.46 & & HB & 0.45 & $*$ \\
\hline NW & 0.45 & & NW & 0.45 & \\
\hline Average & 0.61 & & Average & 0.60 & \\
\hline
\end{tabular}

${ }^{1}$ SN: 2014; NI: 2017; BY, BE, HB, HH, HE, MV, RP, SL, ST, SH: 2020.

${ }^{2}$ Rule from 2015 on: 0.62 .

A dark grey marking indicates that a new rule, according to the federal debt brake, has been implemented in the state's constitution, a light grey marking that only the $L H O$ or a simple law got changed, and no marking shows that no new rule has been implemented, yet.

Source: Own calculation.

From 2020 on, Saxony (0.76) displays the strongest rule, followed by RhinelandPalatinate (0.69), Hamburg (0.67), Bavaria (0.66), Schleswig-Holstein (0.66) and Thuringia (0.66). Except for Thuringia all these states implemented the rule in their state constitutions. What makes Saxony outstanding is that its rule also covers special funds (except for the fund for pensions) and defines key terms precisely. This raises the index scores significantly.

States with financial support currently score well, but fall back in 2020. The temporary improvement of their rules' credibility is mainly a result of the con- 
solidation transfers' conditionality. All states that changed their constitution range in the upper half once the constitutional change has become effective. Many states implemented a new rule by simple law; they could improve their index score by introducing it into the constitution. Another rather simple way to improve the index score is to take account of all flexibility cases and to define key terms precisely. Extending the coverage of the rule may be politically courageous but beneficial for the rule's credibility. Accordingly, all states that did not change their budget rules range in the lower half. Except for North-Rhine Westphalia, all states ranging at the bottom changed their rules already by constitutional amendments.

Interestingly, credible future rules are by no means confined to wealthy states. A number of poorer states, which are recipients in Germany's fiscal equalization system, have opted for strict rules to improve their budgetary credibility. Conversely, some of the wealthier states are among those with less ambitious rules.

\section{Conclusions}

Further research is, of course, needed to verify whether the new and heterogeneous set of fiscal rules effectively influences deficit behaviour of German states. It certainly needs a far greater number of observations from the 'debt brake era' to allow for meaningful econometric approaches.

Nevertheless, for the case of Germany this study confirms the expectation that national debt rules may not be able to guarantee a homogeneous set of effective fiscal rules across sub-national jurisdictions. In federal countries, states mostly enjoy constitutional and fiscal autonomy and make use of it with respect to the definition and specification of a debt brake - the difference between the state with the lowest (both for the current and the future rule: North-Rhine Westphalia) and the one with the highest index score (for the current rule: SaxonyAnhalt and Schleswig-Holstein and for the future: Saxony) is 0.32 for the current and 0.31 for the future rule. However, although the Grundgesetz prohibits borrowing only from 2020 onwards, already 11 out of the 16 states implemented new rules and discuss their specification further. This indicates a significant awareness of the debt problem as such and that the federal constitution's innovation has induced state law adjustments.

However, this does not hold for some highly indebted states. The detailed analysis reveals striking details: Some states that are heavily indebted or receive financial support do not show much ambition so far. Among the five states that 
receive consolidation support payments, only Saxony-Anhalt and SchleswigHolstein implemented a stronger rule to meet the federal debt brake requirements. The three other states' rules benefit from a temporary sanction threat. This rule strengthening element is, however, temporary and exposed from outside as it is an implication of the federal debt brake.

Some of the highly indebted states miss, thus, the chance of using their own legislation to make their fiscal regime more credible. This observation is in line with well-known disincentives of German federalism. Germany's federal jurisdictions form a bail-out-community. As a consequence, states' bond yields do not differ to any significant extent and there are no incentives to regain capital market reputation through better rules. Any such signal does not pay off in terms of financing costs, but it may produce political costs. In this sense, the German experience is another example of the general disincentives related to federal institutions based on mutual bailout promises. In the light of the upcoming discussions regarding German fiscal federal institutions, these results should be kept in mind.

Finally, our observations are of relevance for all attempts to improve fiscal governance in federal systems, especially in the euro area through new prescriptions, such as the Fiscal Compact or the reformed Stability and Growth Pact. A particular attention in the implementation of all these new rules has to be given to the federal dimension. Germany is a clear example, where a seemingly unequivocal country-wide deficit rule does not necessarily create a budgetary level playing field across all sub-national jurisdictions, although judicial ties are a lot stronger than they are at the supranational, European level. 


\section{Appendix:}

\section{Exemplary Index Score Calculation for Baden-Württemberg}

The full set of state sheets is available at www.zew.de/zse_fri13.

\begin{tabular}{|c|c|c|c|c|c|c|c|}
\hline \multirow[t]{2}{*}{ Categories } & \multicolumn{4}{|c|}{ Part of Rule } & \multirow{2}{*}{\multicolumn{2}{|c|}{ Total Points }} & \multirow[t]{2}{*}{$\begin{array}{l}\text { Std. } \\
\text { Points }\end{array}$} \\
\hline & $\begin{array}{l}\text { Basic } \\
\text { rule }\end{array}$ & Regulations & Relaxations & Sanctions & & & \\
\hline Description & $\begin{array}{l}\text { BBR: } \\
\text { balanced } \\
\text { budget }\end{array}$ & $\begin{array}{l}\text { "In principle" } \\
\text { no borrowing } \\
\text { (considering } \\
\text { business cycle } \\
\text { developments), } \\
\text { deviations are } \\
\text { recorded on a } \\
\text { control ac- } \\
\text { count, decreas- } \\
\text { ing limits for } \\
\text { borrowing } \\
\text { until 2019; } \\
\text { additional tax } \\
\text { income used } \\
\text { for debt re- } \\
\text { demption }\end{array}$ & $\begin{array}{l}\text { Borrowing } \\
\text { allowed in } \\
\text { case of } \\
\text { natural } \\
\text { catastrophes } \\
\text { or extraordi- } \\
\text { nary emer- } \\
\text { gencies, } \\
\text { simultane- } \\
\text { ously decide } \\
\text { redemption } \\
\text { plan (ade- } \\
\text { quate time } \\
\text { span) }\end{array}$ & $\begin{array}{l}\text { A fourth of the } \\
\text { Parliament's } \\
\text { members or } \\
\text { the govern- } \\
\text { ment can take } \\
\text { the budget to } \\
\text { the constitu- } \\
\text { tional court; } \\
\text { the Stability } \\
\text { Council moni- } \\
\text { tors enforce- } \\
\text { ment, if a } \\
\text { budgetary } \\
\text { emergency } \\
\text { occurs, the } \\
\text { Council sets up } \\
\text { and monitors } \\
\text { the financial } \\
\text { restructuring } \\
\text { programme }\end{array}$ & & & \\
\hline A Legal base & $\begin{array}{l}\text { Constitu- } \\
\text { tion art. } \\
79(1) \\
\text { sentence } \\
2, \text { LHO } \\
\text { art. } 18 \\
(1) \\
4\end{array}$ & $\begin{array}{l}\text { Constitution } \\
\text { art. } 79, \text { LHO } \\
\text { art. } 18(1-5) \text {, } \\
\text { Coalition } \\
\text { Agreement } \\
2011 \\
3\end{array}$ & $\begin{array}{l}\text { BBR: consti- } \\
\text { tution art. } 84 \\
\text { sentence } 2 \text {, } \\
\text { LHO art. } 18 \\
\text { (6) } \\
3\end{array}$ & $\begin{array}{l}\text { Constitution } \\
\text { art. } 68 \text { (2) No } \\
\text { 2; Stability } \\
\text { Council: } \\
\text { Federal consti- } \\
\text { tution art. } 109 \text { a } \\
\text { sentence } 1 \text { No } \\
2 \text {, StabiRatG } \\
4\end{array}$ & 14 & & 0.88 \\
\hline $\begin{array}{l}\text { B Enforce- } \\
\text { ment } \\
\text { mecha- } \\
\text { nisms }\end{array}$ & & & & $\begin{array}{l}\text { There are no } \\
\text { specific sanc- } \\
\text { tions (valid for } \\
\text { every bill), the } \\
\text { Stability } \\
\text { Council only } \\
\text { monitors the } \\
\text { enforcement } \\
\text { but cannot } \\
\text { sanction } \\
\text { defections or } \\
\text { impose correc- } \\
\text { tive measures } \\
1\end{array}$ & 1 & & 0.25 \\
\hline
\end{tabular}




\begin{tabular}{|c|c|c|c|c|c|c|c|c|c|}
\hline \multirow{2}{*}{\multicolumn{2}{|c|}{ Categories }} & \multicolumn{4}{|c|}{ Part of Rule } & \multicolumn{3}{|c|}{ Total Points } & \multirow{2}{*}{$\begin{array}{l}\text { Std. } \\
\text { Points }\end{array}$} \\
\hline & & $\begin{array}{l}\text { Basic } \\
\text { rule }\end{array}$ & Regulations & Relaxations & Sanctions & & & & \\
\hline & Coverage & & 1.5 & & & 1.50 & I & & 0.38 \\
\hline & $\begin{array}{l}\text { Official } \\
\text { budget: }\end{array}$ & & 0.5 & & & 0.5 & I & 1 & 0.50 \\
\hline & $\begin{array}{l}\text { - share- } \\
\text { holdings }\end{array}$ & & 1 & & & & & & \\
\hline & $\begin{array}{l}\text { - debt } \\
\text { claims by } \\
\text { public } \\
\text { authorities }\end{array}$ & & 0 & & & & & & \\
\hline & $\begin{array}{l}\text { - granted } \\
\text { loans }\end{array}$ & & 1 & & & & & & \\
\hline & - reserves & & 0 & & & & & & \\
\hline & $\begin{array}{l}\text { Public } \\
\text { enterprises }\end{array}$ & & 0 & & & 0 & I & 1 & 0.00 \\
\hline & $\begin{array}{l}\text { Special } \\
\text { funds }\end{array}$ & & 0 & & & 0 & I & 1 & 0.00 \\
\hline & $\begin{array}{l}\text { Financial } \\
\text { support for } \\
\text { local au- } \\
\text { thorities }\end{array}$ & & 1 & & & 1 & I & 1 & 1.00 \\
\hline \multirow[t]{5}{*}{ D } & Flexibility & & 1 & 3 & & 4 & I & 4 & 1.00 \\
\hline & $\begin{array}{l}\text { Business } \\
\text { cycle }\end{array}$ & & 1 & & & 1 & I & 1 & 1.00 \\
\hline & $\begin{array}{l}\text { Economic } \\
\text { shocks }\end{array}$ & & & 1 & & 1 & 1 & 1 & 1.00 \\
\hline & $\begin{array}{l}\text { Other } \\
\text { emergencie } \\
\text { s }\end{array}$ & & & 1 & & 1 & I & 1 & 1.00 \\
\hline & $\begin{array}{l}\text { Compensati } \\
\text { onal } \\
\text { mechanism }\end{array}$ & & & 1 & & 1 & I & 1 & 1.00 \\
\hline \multirow{2}{*}{\multicolumn{2}{|c|}{$\begin{array}{l}\text { E Content } \\
\text { Clear } \\
\text { definitions }\end{array}$}} & \multirow[t]{2}{*}{1} & 5 & 3 & 3 & 12 & I & 20 & 0.60 \\
\hline & & & $\begin{array}{l}\text { Borrowing: } 2 \\
\text { (speficied in } \\
H G r G \text { ) }\end{array}$ & $\begin{array}{l}\text { Natural } \\
\text { catastrophe: } \\
2 \text { (not speci- } \\
\text { fied in detail } \\
\text { but general } \\
\text { understand- } \\
\text { ing, use must } \\
\text { be justified) }\end{array}$ & $\begin{array}{l}\text { Legal provi- } \\
\text { sions are } \\
\text { clearly defined }\end{array}$ & & & & \\
\hline
\end{tabular}




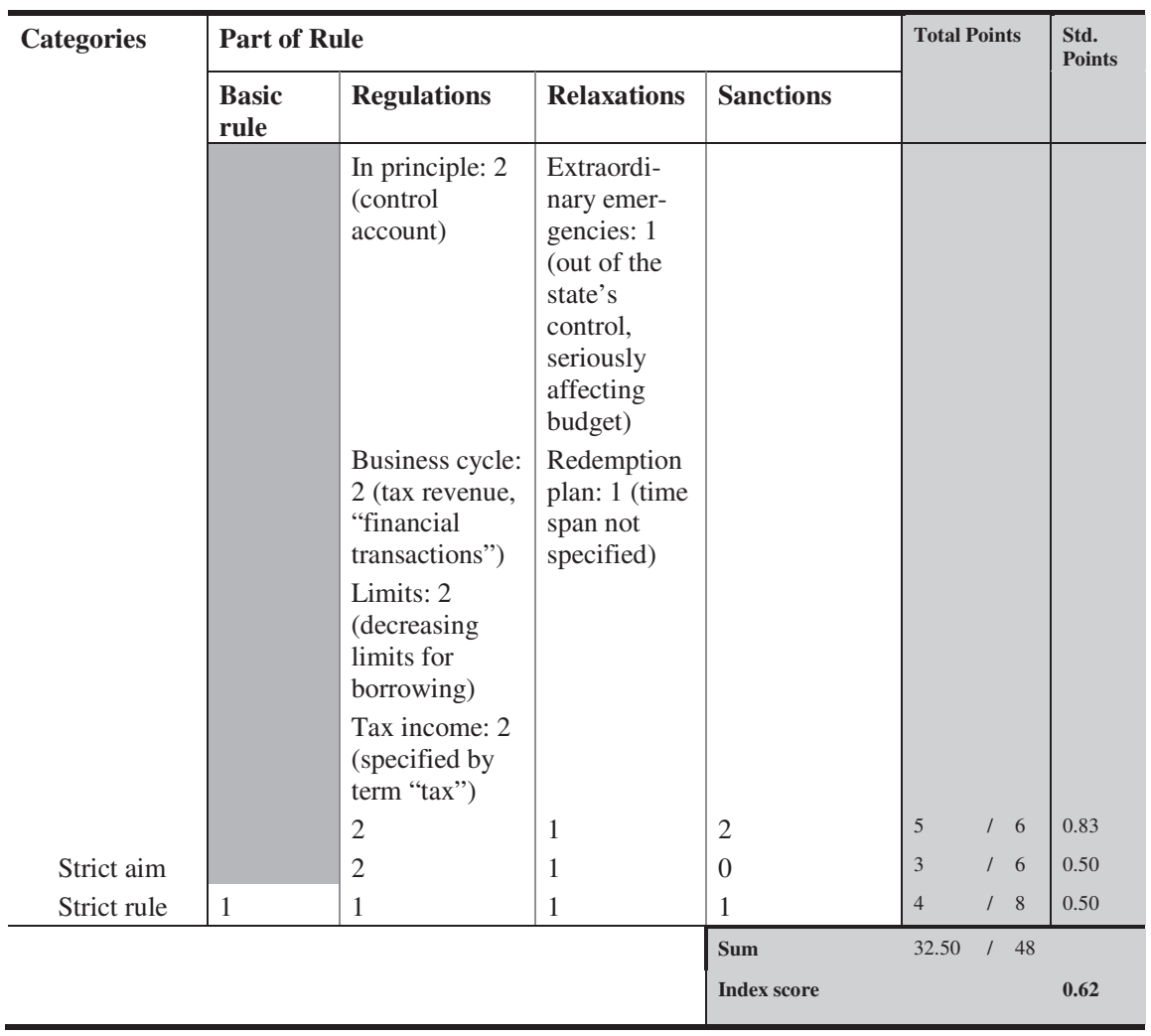

Source: Own calculation. 